\title{
Guidance for Developing a Research Data Management (RDM) Policy
}

This document provides the essential elements of a Research Data Management (RDM) Policy and is part of the LEARN Toolkit containing the Model Policy for Research Data Management (RDM) at Research Institutions/Institutes.

The elements below may be used to define research data, explain RDM, illustrate workflows, point out benefits and give information about funding agency requirements. Please note that in order to facilitate the measurability of the policies and their impact, they should be created in a machine actionable format. Furthermore, indicators may be used for automated validation processes.

\begin{tabular}{|c|c|}
\hline Elements & Description \\
\hline Header info & $\begin{array}{l}\text { Document title } \\
\text { Institutional logo }\end{array}$ \\
\hline Title of policy & Description of the pursued issue \\
\hline Subtitle & If necessary: extension of the title \\
\hline $\begin{array}{l}\text { General remarks } \\
\text { before getting } \\
\text { started }\end{array}$ & $\begin{array}{l}\text { > Research data is one part of the knowledge capital of research institutions. In data-driven science, good } \\
\text { data management promotes discovery, efficiency, and increases reliability by ensuring consistent quality } \\
\text { with a high level of comparability. The policy may be strongly connected to strategic alignments and strategic } \\
\text { management. It could help in building the bridge from technical requirements to skills and competencies. } \\
\text { > Research data management is considered as a whole in the policy } \\
\text { (including research records, methods, software, code etc.). } \\
\text { > These principles will determine the organisation's behaviour. } \\
\text { > These principles also apply to the behaviour of individuals within the institution. } \\
\text { > The policy (with annexed documents) should contain definitions, indicating answers to these questions: } \\
\text { - What is "research data"? } \\
\text { - What is "research"? } \\
\text { - Who is a "researcher"? } \\
>\text { The following should be clear: } \\
\text { - Authorship of the policy. It should be clear who defines the policy ("the } \\
\text { speaking entity") and why this entity (author of the policy) defines the } \\
\text { policy. What is the role of "the speaking entity" (authorship)? } \\
\text { - Aim of the policy. Why does a research institution/institute have a policy? What } \\
\text { is the goal of the policy? What does the institution want to achieve? } \\
\text { - Subject. According to the statutes of the institution and its published } \\
\text { guidelines: What is the subject of the policy? }\end{array}$ \\
\hline
\end{tabular}




\begin{tabular}{|c|c|}
\hline $\begin{array}{l}\text { Preamble } \\
\text { Refers to Point } 1 \text { of } \\
\text { the Model Policy }\end{array}$ & $\begin{array}{l}\text { The preamble describes the context: } \\
>\text { It is an introductory statement or a description of an initial situation. } \\
>\text { It defines why there should be a policy and how to contextualize it within the institutiton. This part has to } \\
\text { be localised by each institution and aligned with the prevaliling philosophy and mission of the institution. } \\
\text { > Scientific disciplines and organizations produce and manage different types of } \\
\text { materials which might have different guiding principles. It ti essential that consistency } \\
\text { is brought to the field in the form of research institution/institute--level policies. } \\
>\text { The fundamental truths or propositions that serve as the foundation for } \\
\text { the chain of reasoning of the policy should be described. }\end{array}$ \\
\hline $\begin{array}{l}\text { Jurisdiction } \\
\text { Refers to Point } 2 \text { of } \\
\text { the Model Policy }\end{array}$ & $\begin{array}{l}\text { > The scope of the policy must be defined according to space and time. } \\
\text { > The relationship between the policy and research institutuon/institute and non-research } \\
\text { institution/institute guidelines and statutes must be clarified in the policy. } \\
\text { > Compliance with legal and contractual provisions must be maintained. }\end{array}$ \\
\hline $\begin{array}{l}\text { Intellectual } \\
\text { Property Rights } \\
\text { Refers to Point } 3 \text { of } \\
\text { the Model Policy }\end{array}$ & 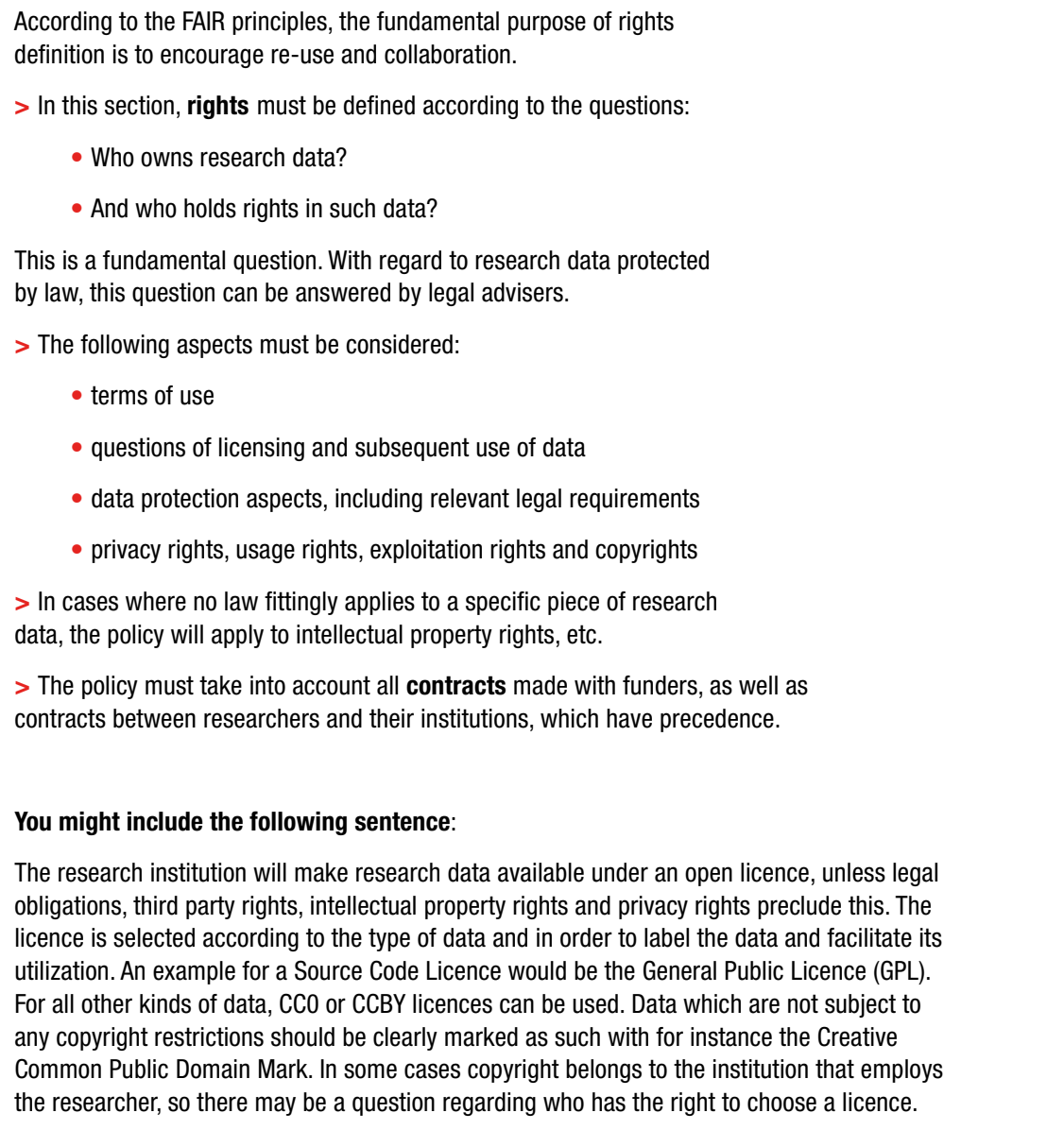 \\
\hline
\end{tabular}

\begin{tabular}{|c|c|}
\hline $\begin{array}{l}\text { Handling } \\
\text { research data } \\
\text { Refers to Point } 4 \text { of } \\
\text { the Model Policy }\end{array}$ & 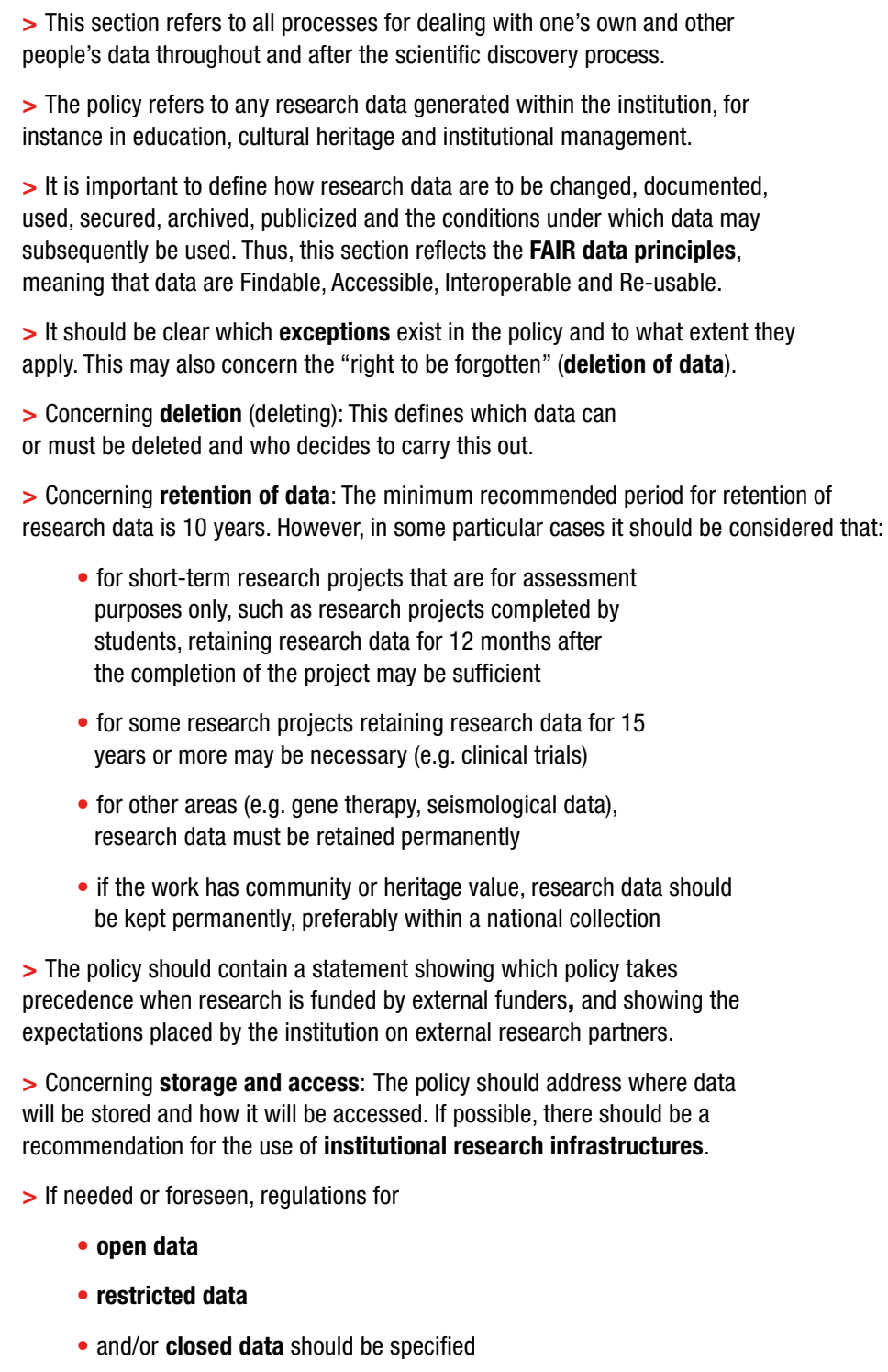 \\
\hline
\end{tabular}




\begin{tabular}{|c|c|}
\hline $\begin{array}{l}\text { Responsibilities, } \\
\text { Rights, Duties } \\
\text { Refers to Point } 5 \text { of } \\
\text { the Model Policy }\end{array}$ & $\begin{array}{l}\text { This section defines the coverage of the policy: } \\
\text { - institutional } \\
\text { - faculty-wide (or other organizational units) } \\
\text { - discipline-wide } \\
\text { - group(s) of people covered: such as research staff, research support staff, IT services, students } \\
>\text { The scope and coverage of the policy should be checked: } \\
\text { - Does the policy include all research data? } \\
\text { - Does the policy include/exclude a selection of the non-digital results of research processes? } \\
>\text { Regulations concerning the responsibilities, rights and duties of the following } \\
\text { persons and institutions should be formulated with regard to research data: } \\
\text { - researchers and research data producers (e.g. PhD students) } \\
\text { - funders and funders' regulations (the policy should acknowledge that funders have rights } \\
\text { and regulations, and show that these will be given precedence where appropriate) } \\
\text { - institutions } \\
\text { - research supporting entities (for example, libraries, IT services, research support centres, etc.) } \\
>\text { If necessary, there should be a recommendation for institutional research infrastructure. } \\
>\text { Questions around the costs of RDM (including stewardship of data) as stated in } \\
\text { a data management plan (DMP), as well as who bears those costs, should be well } \\
\text { defined. This could also include costs that occur after a project has ended. } \\
>\text { It is important to define roles, responsibilities and competencies in order } \\
\text { to assign objectives and define time frames. Relevant questions: } \\
\text { - Who is in charge of ensuring legal compliance? } \\
\text { - Who will provide legal advice? } \\
\text { - Who is in charge of the quality of the content? } \\
\text { - Who is in charge of defining acceptable formats? } \\
\text { - Who is in charge of maintaining the currency of formats over time? } \\
\text { - Who will provide technical support? } \\
\text { - Will promote services? } \\
\text { provide training? }\end{array}$ \\
\hline $\begin{array}{l}\text { Approval of the } \\
\text { policy, periodic } \\
\text { review, validity } \\
\text { and timeline } \\
\text { Refers to Point } 6 \text { of } \\
\text { the Model Policy }\end{array}$ & $\begin{array}{l}\text { > This pertains to the date of release of the policy and how long the current } \\
\text { policy will be valid. This can be done on a regular basis, which may be externally } \\
\text { defined, or based upon needs. The key dates must be included. } \\
>\text { The policy should be subjected to periodic review. The changes in each revision must be listed. } \\
>\text { The relevant questions here are: } \\
\text { - How long are the terms of the policy valid? } \\
\text { - Who/which body is responsible for reviewing and updating the policy? } \\
\text { - What should be done after the end of the defined timeline or period? }\end{array}$ \\
\hline Footer info & $\begin{array}{l}\text { - Page number } \\
\text { - Version number } \\
\text { - Status } \\
\text { - etc. }\end{array}$ \\
\hline $\begin{array}{l}\text { Annexes } \\
\text { Refers to Annex } \\
\text { of Model Policy }\end{array}$ & $\begin{array}{l}\text { - Definition of key terms } \\
\text { - Excerpts from / links to relevant funder policies or expectations } \\
\text { - List of related institutional policies (with links) }\end{array}$ \\
\hline
\end{tabular}

See also the LEARN Project Glossary: http://learn-rdm.eu/en/dissemination/glossary/; last accessed 12/2/17 